\title{
ANALYSIS OF LANDSLIDES CAUSES ON BTS. KOTA BATU - BTS. KAB. KEDIRI ROAD
}

\author{
Dewi Atikah ${ }^{1}$ \\ ${ }^{1}$ Bina Marga Public Works, East Java Province \\ e-mail: d3wi.atikah@gmail.com
}

\begin{abstract}
Landslides can occur due to decreased slope stability due to soil degradation and rock degradation making up the slopes. The problem of land mass movement occurred in the Bts. Kota Batu - Bts. Kab. Kediri Road (Link 187) Ngroto Village, Pujon District, Malang Regency, precisely at KM Mlg 31+350. This study is to determine the cause of the landslide on the Bts. Kota Batu - Bts. Kab. Kediri (Link 187) KM Mlg 31+350 and to find out the appropriate handling method to overcome the landslide. The factors causing landslides were analyzed from various sides as follows: due to existing conditions, due to changes in land use, topographic conditions, and geological conditions. The selection of the handling method, according to the situation and conditions in the field, is the use of a masonry retaining wall structure, the application of sheet piles, the handling of groundwater around the landslide area, and the normalization of rivers.
\end{abstract}

Keywords: Landslides; Landslide Caused Factors; Handling Methods

\section{Introduction}

Landslides can occur due to decreased slope stability due to soil degradation or rock making up the slopes. Road and bridge infrastructure, if they are located on soil or rock whose property characteristics are prone to landslides, must be given special handling. Landslides that disrupt the smooth flow of transportation will hamper the economy of a region.

To be able to handle the occurrence of landslides or soil mass movements, an analysis of the causes of ground movements is needed. The results of this analysis will be used as a basis for proper mitigation of landslides. The problem of land mass movement occurred in Bts. Kota Batu - Bts. Kab. Kediri (Link 187) Ngroto Village, Pujon District, Malang Regency, precisely at KM Mlg 31+350. The road section is a provincial road section. In this regard, this study aims to analyze the causes of landslides. Based on the results of the analysis of the causes of the landslide, it will be used as a basis for determining alternative handling for landslides at that location.

\section{Materials and Methods}

The movement of the soil mass in the form of landslides occurs due to shear failure along the landslide area which is the limit of the movement of the soil or rock mass [1]. Soil movement occurs as a result of a balance disturbance which is the result of a process of water infiltration into the soil which results in an increase in soil weight. If the water penetrates to the impermeable soil which acts as a slip plane, the soil will become slippery and the soil above it will move along the body of the slope. Mass motion on the slope occurs when the shear resistance of the soil is less than the weight of the soil mass.

Indonesia, which is on the equator, has quite high rainfall, supported by fertile soil conditions, so that the vegetation that grows on it becomes shady. Mountainous or hilly areas with dense vegetation store infiltrated rainwater into the soil. Rainwater stored in the soil layer, when added in 
volume by rainwater that comes with high intensity, can cause an increase in the pore water content in the soil. This positive increase in pore water will cause soil collapse.

According to Cruden and Varnes in [1], the characteristics of soil mass movement on slopes are: fall, collapse (topple), avalanche (slides), spread and flow. Flow is the movement of crushed material down a slope and flows like a viscous liquid. The movement of the material occurs in different shear planes and the moving mass has a very high water content. The soil absorbs a lot of water and turns into slurry [1]. Landslides are prone to flow types that occur in mountainous areas, hills or valleys flanked by steep slopes and receive high intensity rain.

Broms (1975) in [1] divides the type of landslide as follows:

1. Earth flow. Soil runoff often occurs in clay and silt soils after high-intensity rains. Movement speed varies from slow to very high.

2. Flow of mud / silt (mud flow). Silt/mud flow can occur in sloping areas on cracked clay or solid clay between layers of fine sand with high pore water pressure, or also due to erosion of the sand layer.

3. The flow of debris (debris flow). Debris flow is a flow that occurs in coarse-grained materials. This flow often occurs in dry areas with sparse vegetation, or slopes without vegetation. Debris flows often occur during heavy rains or sudden floods. These flows often hit areas up to several kilometers. Debris flow can be in the form of ground movement together with water and air flowing rapidly on lower slopes.

4. Avalanche flow (flow slide). Landslide is the movement of slope-forming material due to liquefaction in a layer of fine sand or silt that is not densely submerged in groundwater. Avalanches can occur due to high pore water pressure or due to vibration. Excess pore water causes the soil to lose its shear strength and turn into a viscous liquid.

The method used in this analysis is descriptive method. According to [6] qualitative descriptive methods are: research methods based on the philosophy of post positivism used to examine the condition of natural objects (as the opposite is experiment) where the researcher is the instrument The key to data collection techniques was trigulation (combined), data analysis is inductive/qualitative, and the results of qualitative research are more emphasize meaning rather than generalization. Descriptive research qualitative aims to describe, describe, explain, explain and answer in more detail the problem which will be researched by studying as much as possible an individual, a group or an event.

A study cannot be separated from data. Data collection techniques are a method used by a researcher to collect the data needed in research [7]. The data in this study were collected from observation. Observation, according to [7], is a systematic observation and recording of the elements that appear in a symptom in the object of research. The visible elements are called data or information that must be observed and recorded correctly and completely. This method is used to see and observe directly conditions in the field so that researchers get a broader picture of the problem under study. As for the observations that will carried out is by making direct observations of the Bts. Kota Batu Bts. Kab. Kediri (Link 187) KM Mlg 31+350 road.

The stages in this research are as follows:

1. Analysis based on chronological data of events.

2. Secondary data collection: secondary data required are location maps, landslide hazard maps and geological maps of the research area, geoelectrical results on these roads, and results of seismograph measurements.

3. Field investigation: required to observe the condition of the landslide location. Observations were made on soil movement conditions, topography, soil conditions, drainage channels and vegetation conditions at the site.

4. Data analysis: data analysis was carried out based on the results of observations in the field and secondary data that had been collected. Data analysis will produce conclusions about the mechanism and causes of landslides. 


\section{Results and Discussion}

3.1. Location

The research location is based on a map derived from [10] as shown below. The location of the landslide is on Jalan Bts. Kota Batu - Bts. Kab. Kediri (Link 187) KM Mlg 31+350 to be exact in Ngroto Village, Pujon District. the location of the landslide road body is flanked by hills and river valleys.

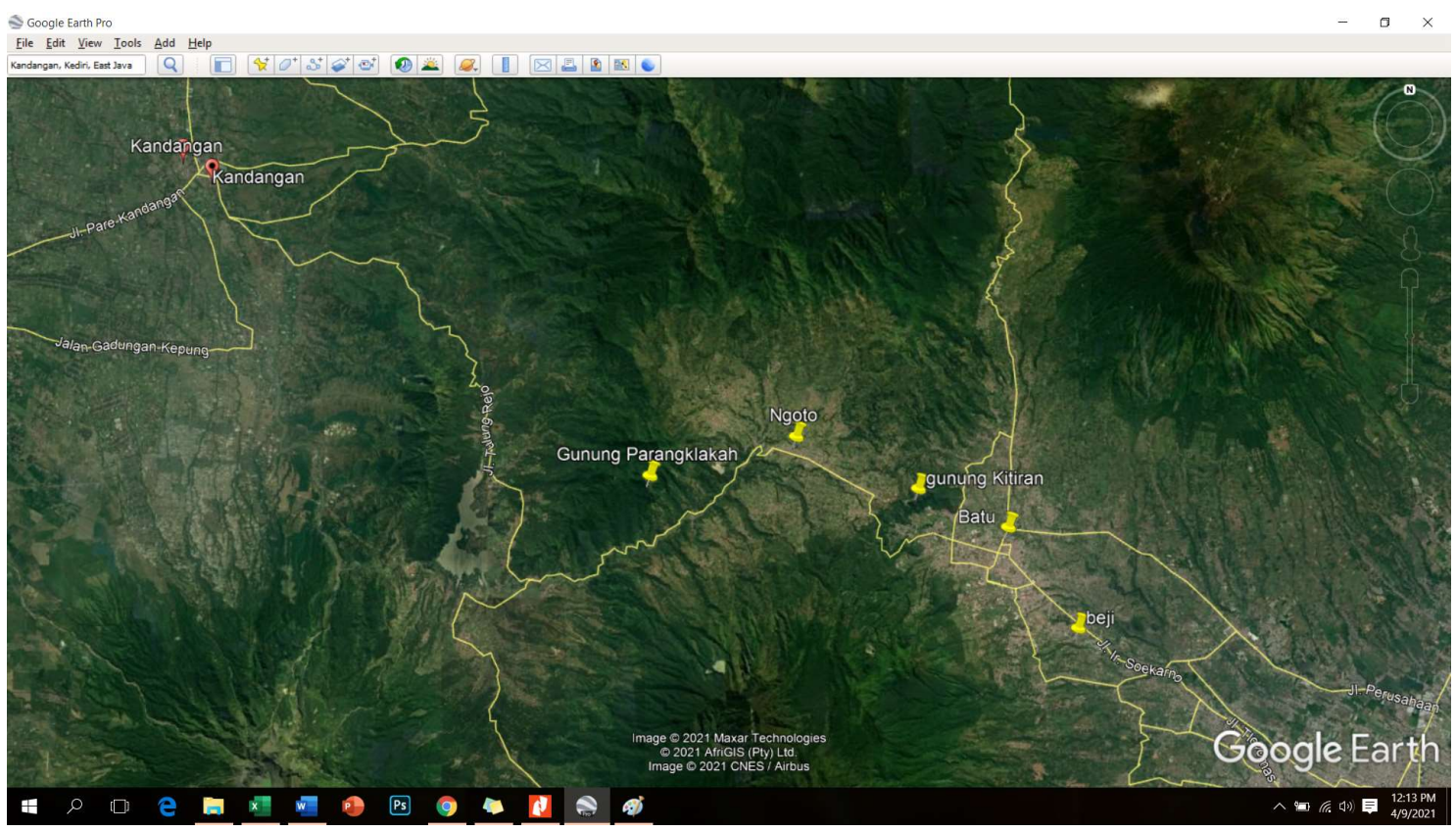

Figure 1. Map Location

\subsection{Chronology}

1. It rained on February $19^{\text {th }}, 2021$ at around 6.00 WIB in Ngroto Village, Pujon District, Malang Regency which resulted in a Natural Disaster on the Bts. Kota Batu - Bts. Kab. Kediri (Link 187) $\mathrm{Km}$. M.Lang $31+350$ in the form of a road body that has cracked and subsidence as well as scouring is $\pm 25 \mathrm{~m}$ long, $1.5 \mathrm{~m}$ wide and $4.2 \mathrm{~m}$ deep.
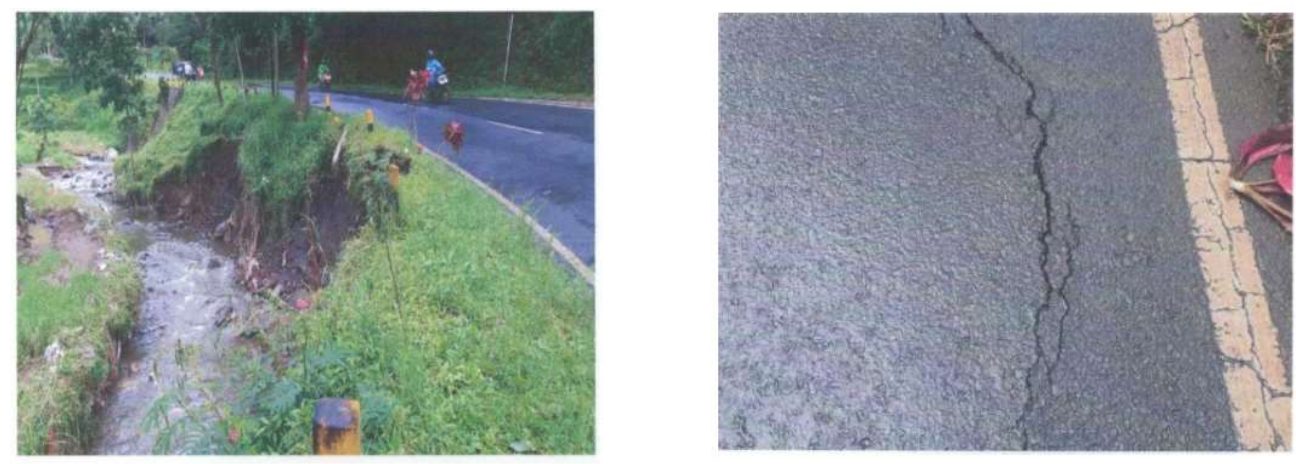

Figure 2. Photos of Early Avalanches and Early Cracks

2. On February 28th, 2021, the avalanche has reached the edge of the pavement with a length of \pm $25 \mathrm{~m}$, a width of $3 \mathrm{~m}$ and a depth of $4.2 \mathrm{~m}$. 


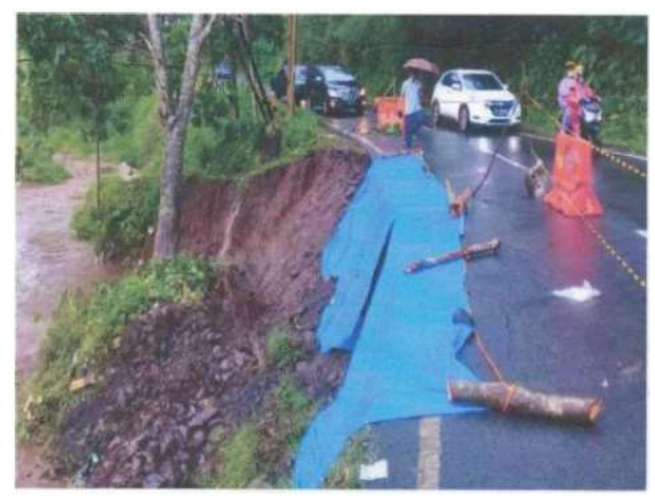

Figure 3. Avalanche to the edge of the pavement

3. On February 4th, 2021 the road damage increased to half of the road body which could potentially damage the entire road so that the road cannot be passed.

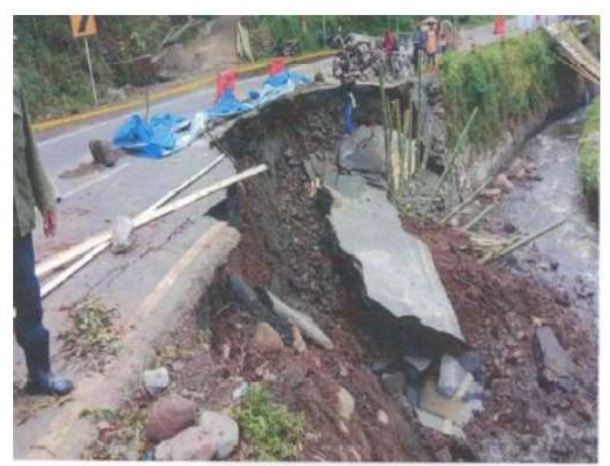

Figure 4. Avalanche up to the road body

4. On March 6th, 2021, there was another landslide that was getting worse, causing the road body to sink more than half of the road, the scouring was getting wider and the cracks were getting wider, as well as pressure and vibration from vehicles passing above the location.

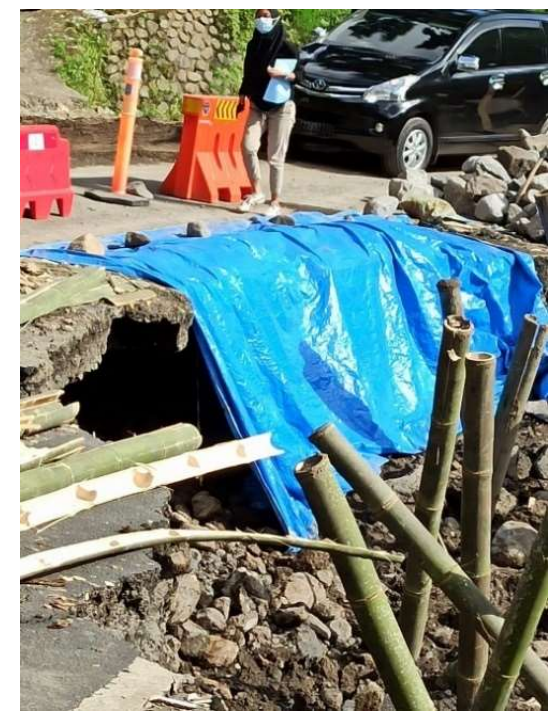

Figure 5. Avalanche of more than half of the road 
5. Improvements continue to be made by making masonry and niches as shown below. However, it turned out that there was a flow avalanche (liquefaction) in the form of water mixed with sand from the cliff towards the river area from under the road body so that the installed cerucuk collapsed. The liquefaction process caught on camera. The flow of sand mixed with water from the side of the road on the side of the slope pushes the bamboo into the river valley. The flow of watery sand stopped flowing because it was blocked by a large log which was thought to have been buried since ancient times.
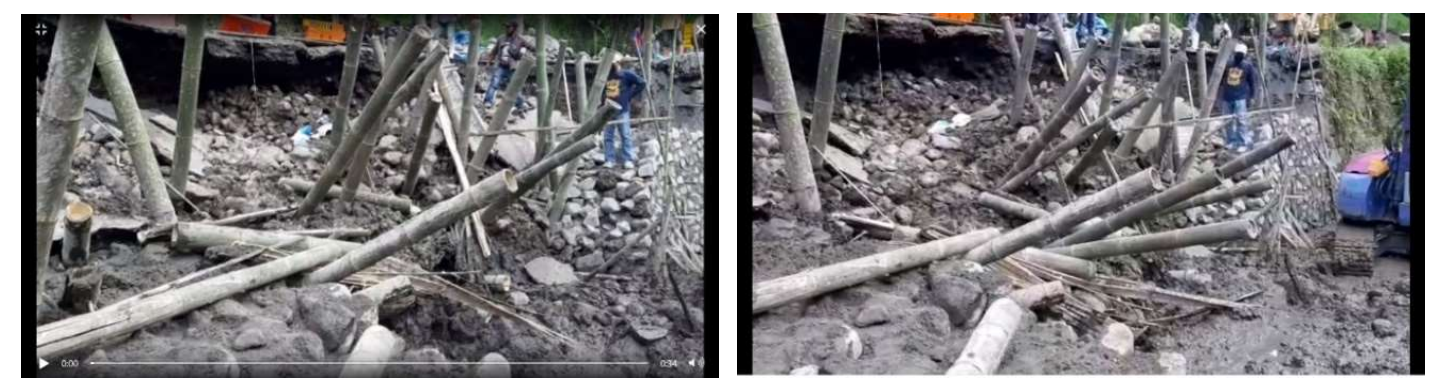

Figure 6. Avalanche Flow Process

Based on the chronology above, a hypothesis is obtained about the type of landslide at that location. At the beginning of the failure, the type of soil mass movement, there was a rotational landslide, because it had a curved landslide area. Then in the final phase of the avalanche, a liquefaction flow avalanche occurs, because there is a thick liquid coming out of the inside of the road leading to the valley.

3.3. The factors that cause landslides are analyzed from various factors as follows:

a. Existing Condition

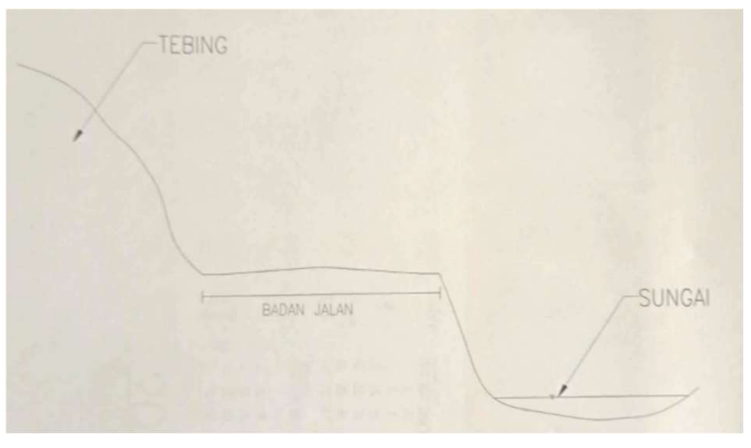

Figure 7. Avalanche Location Sketch

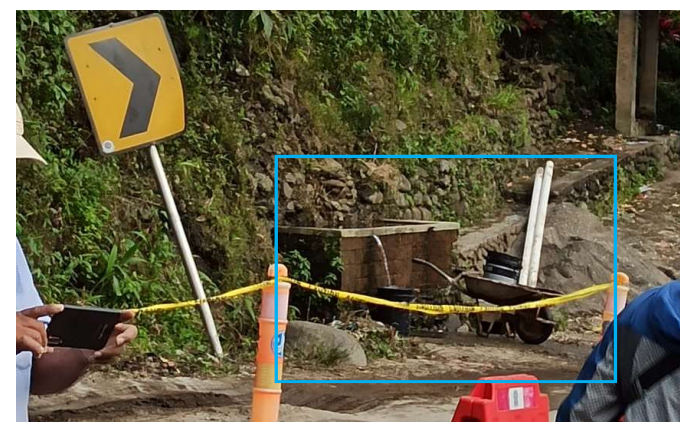

Figure 8. Springs at the Landslide Location 
Bts. Kota Batu - Bts. Kab. Kediri. Apart from being adjacent to the slopes on the left side, Kediri is also bordered by the Konto Hulu tributary on the right side, according to the sketch in Figure 7. In addition, there is a spring that continues to flow from the cliff on the left side of the road, which is accommodated by the surrounding community (Figure 8).

b. Land Use Change

The existing condition of the road on the side of the river began to decline after a change in land use at that location. There are activities of residents who stockpile the outside of the river to enlarge their plantation area. The hoarding resulted in the narrowing of the wet cross section of the river. The river water began to look for other channels, so it began to erode the lower side of the roadside slope, which gradually eroded the foundation of the road body. Changes in the structure of the foundation slope of the road body result in the appearance of cracks on the road surface. With the appearance of cracks or gaps, rainwater can also enter the soil layer under the road, thereby reducing the shear strength of the soil.

Based on the map of estimation of landslide susceptibility in Pujon District, Malang Regency by [5], Ngroto village is an area prone to landslides, as shown in the picture below:

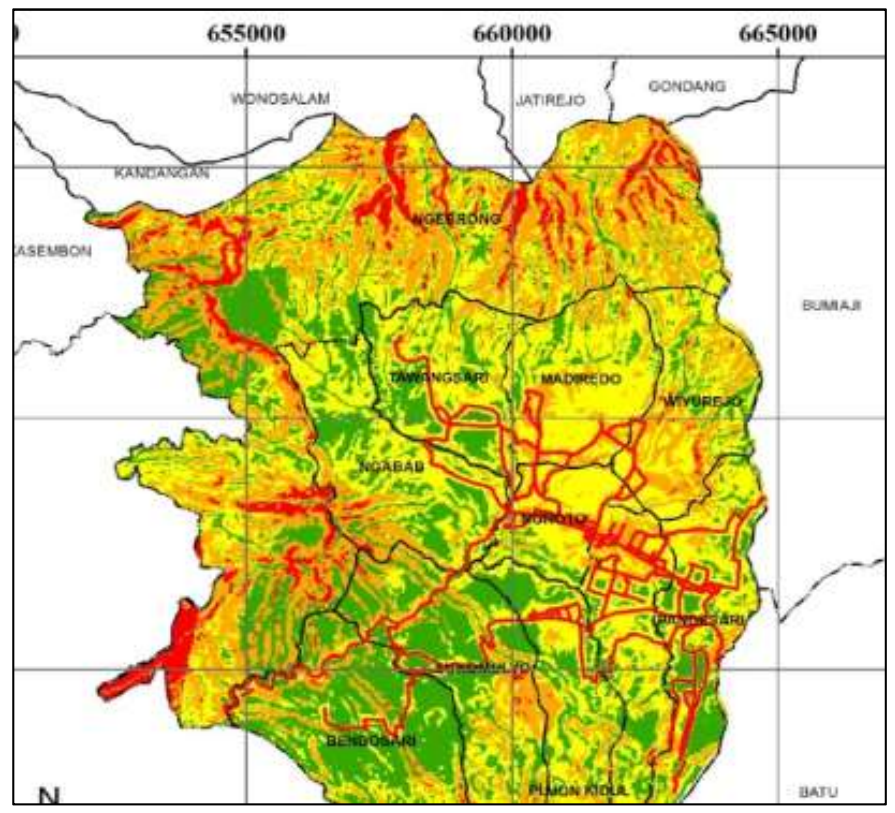

Figure 9. Landslide Hazard Map in Pujon District

Based on the map above, the Bts. Stone Town - Bts. Regency. Kediri, which is in Pujon District, is in an area prone to landslides. Several years earlier, the road from Batu to Kediri had also experienced a landslide.

c. Topographic factors

Based on the topographic map, Ngroto village, Pujon sub-district, is an area classified as mountains or hills. Characteristics of such areas have slopes and valleys. According to [5], the factor that most influences vulnerability to landslides in the Pujon District (Ngroto village) is the presence of slopes. The area is indeed a slope overgrown by various plant vegetation. As many study said that Landslide hazards (soil mass movements) often occur in many places in Indonesia especially in areas of steep / steep slopes [12] [14].

d. Geological factors:

Based on the geological map from [3], the Pujon area with the symbol Qpat (Old Anjasmoro Volcanic Rock) is volcanic breccia, lava, tuff and hacks. This rock is the oldest pyroclastic deposit and is estimated to be of Early to Middle Pleistocene age, which is generally solid and compressed, composed of andesite to basalt, and partially altered. The characteristics of this soil type have a low cohesion value with high permeability. Groundwater can seep easily, thereby 
reducing the value of the shear strength of the soil. If there is a discontinuity area in the lower layer, it will be very vulnerable to landslide hazard. More clearly, the geological formation of Ngroto village can be seen in the image below;

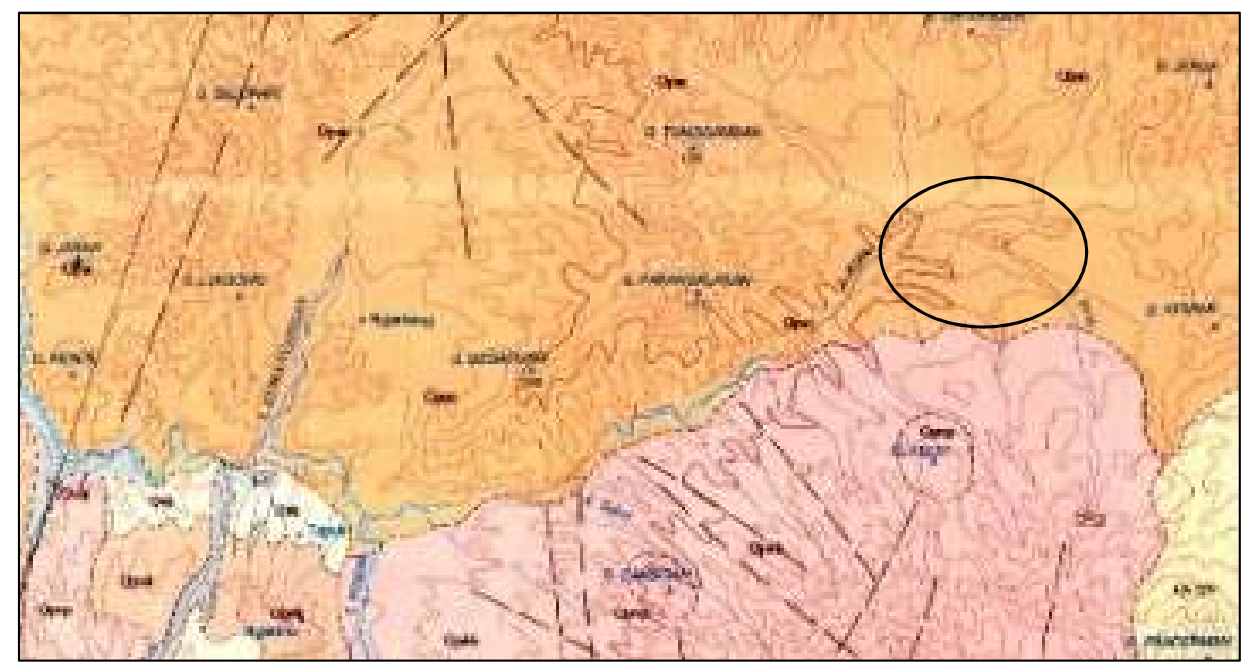

Figure 10. Geological Map

e. The location of the landslide road body is at coordinates 7050' $43.1 \mathrm{~S}$ and $1120266^{\prime} 44.1 \mathrm{E}$. Based on the results of the analysis by [7], the coordinates around the location have stability between $0.30-0.31$. The following is the result of geoelectricity around the landslide location:

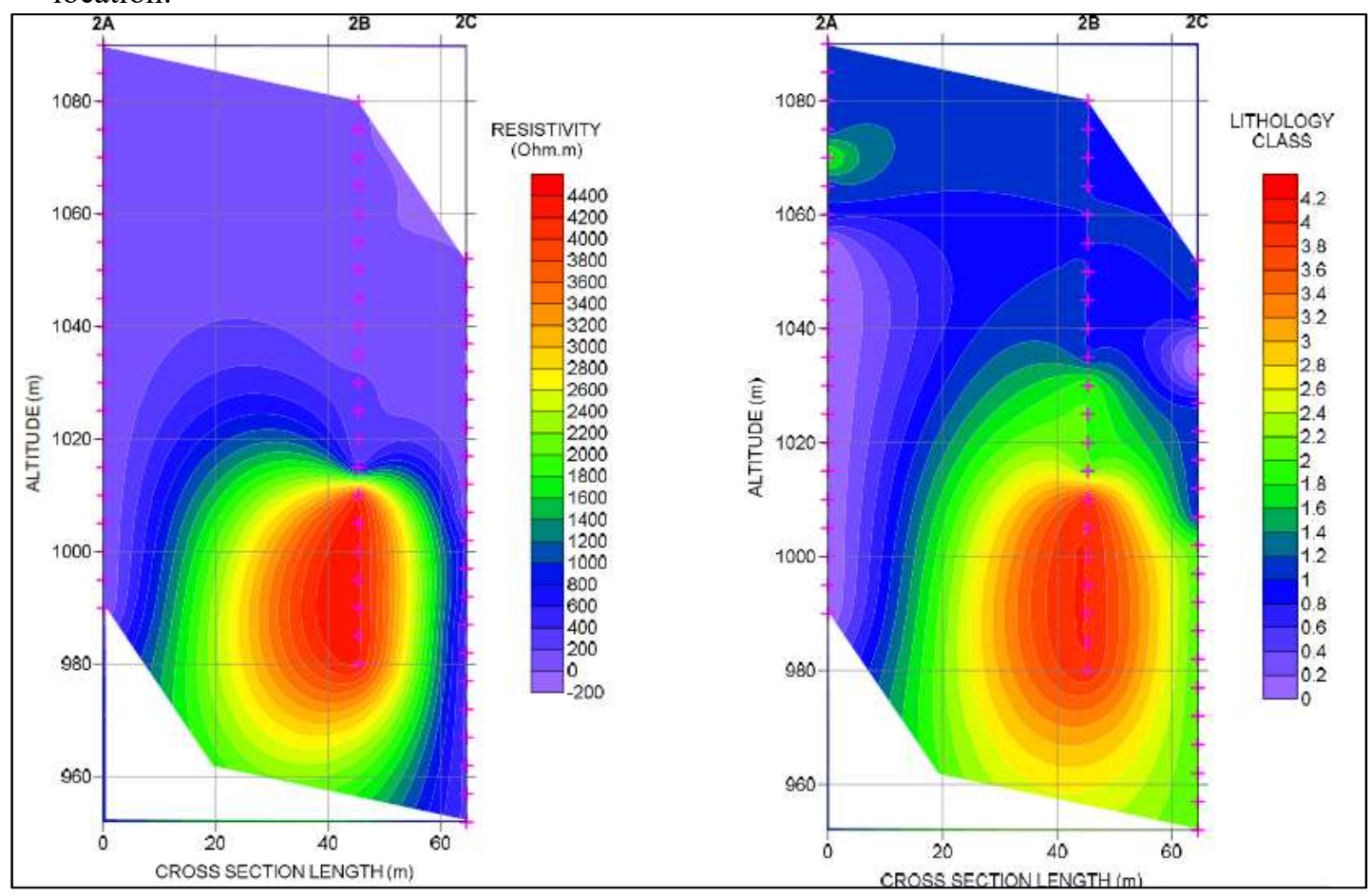

Figure 11. Geoelectricity around the landslide location

f. Soil materials. The soil material at this location is sandy soil. has high permeability. Groundwater can seep easily, thereby reducing the value of the shear strength of the soil. 


\subsection{Alternative Handling}

The selection of countermeasures is adjusted to the situation and conditions in the field. One way to find out the landslide area is to conduct a survey using the Landslide Control Card (KKL) which is compiled based on the the parameters of the factors causing landslides [13]. Factors such as the existing location, slope topography, geology, soil material conditions, and costs are taken into consideration in determining the type of countermeasure. Based on observations at the slope location, taking into account the considerations as mentioned above, the types of countermeasures that can be applied are:

a. Stone masonry retaining wall structure. This wall is made of unreinforced concrete or masonry, sometimes in this type of wall reinforcement is installed on the surface of the wall to prevent surface cracking due to temperature changes [8]. This pair of stones resists the earth's thrust from the slopes and the road towards the river. With pore water holes that must be available to drain groundwater which is considered to still exist around the landslide road body. Stone retaining walls made of stone masonry are relatively cheaper and easier to implement, so this method is more often used as an alternative to landslide resolution.

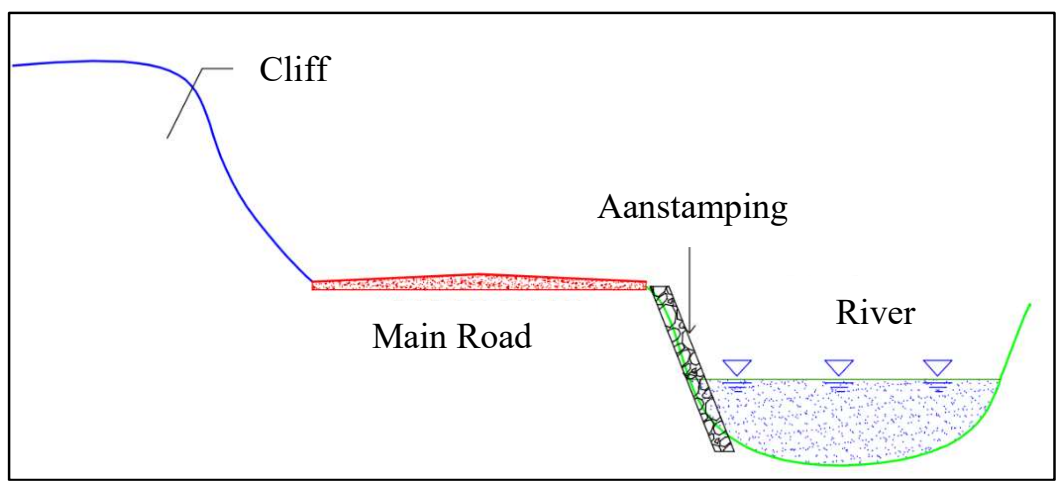

Figure 12. Sketch of Handling with River Stone Pairs

b. In addition, sheetpile applications can also be considered. Sheet pile is a reinforcement that is arranged to resemble the shape of a sheet pile a wall that functions as a retaining cliff, retaining temporary excavations for buildings at the port, retaining soil around the banks of rivers or the sea and others [4]. There are several kinds of material used in sheet piles, namely sheet piles from wood material, sheet pile of concrete material, sheet pile of steel (steel). Sheet piles are arranged in a special shape so that they can be arranged and bind to each other other according to planner's requirement.

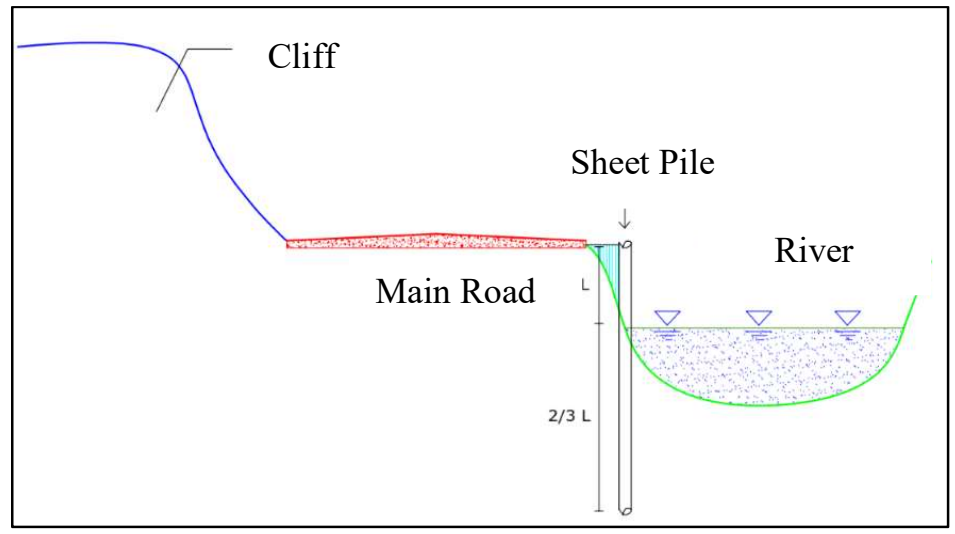

Figure 13. Handling Sketch with Sheetpile 
c. In addition, it is necessary to treat groundwater around the landslide area. Making relief wells can be used as an alternative for sustainable management, considering that around the location there are springs whose water is accommodated by residents. The construction of this relief well is expected to reduce the groundwater level. Furthermore, it is channeled through horizontal drainage which can drain ground water into the canal.

d. What must also be done is the normalization of the river [2]. In accordance with the hypothesis that the factor causing the landslide was a change in land use around the location of the landslide above, the factors causing the change in the direction of the river flow must be eliminated. To avoid scouring river water onto the slopes of the road body which has now been repaired. The road that is directly adjacent to the river is one of the most influential factors in landslides. Keeping the river water flowing smoothly and flowing in the river channel that is currently formed and it is necessary to normalize the river channel with a routine agenda of dredging sedimentation in shallow river channels, so as not to erode the slopes of the road body and not cause landslides.

\section{Conclusions and Suggestions}

4.1. Conclusion

Based on the discussions and descriptions that have been described in previous chapters, the following conclusions can be drawn:

1) Landslide that occurred in Jalan Bts. Kota Batu - Bts. Kab. Kediri (Link 187) KM Mlg $31+350$, Ngroto Village is at the beginning of the collapse, the type of soil mass movement, there was a rotational landslide, because it had a curved landslide area. Then in the final phase of the avalanche, a liquefaction flow avalanche occurs, because there is a thick liquid coming out of the inside of the road leading to the valley.

2) Landslides are caused by existing conditions, changes in land use, topography, geological conditions of the location, and types of soil materials.

3) The proposed countermeasures are masonry retaining wall structures, and the use of sheet piles.

4.2. Suggestion

In handling landslide cases, such as in the Bts. Kota Batu - Bts. Kab. Kediri (Link 187) KM Mlg $31+350$ Ngroto Village, a more detailed investigation stage is needed. Another investigation that is needed is deep drill testing to determine the position of the slip surface of the landslide. Additional investigation and monitoring are needed to support countermeasures to be able to determine more precise countermeasures.

\section{References}

[1] Hardiyatmo, Hary C, "Tanah Longsor dan Erosi Kejadian dan Penanganan", Gadjah Mada University Press. Yogyakarta, 2012.

[2] https:// dspace.uii.ac.id/bitstream/handle/123456789/7863/05.3. BAB $\% 20 I I I \% 20 \% 20 . p d f$ ?sequence $=7 \&$ isAllowed $=y$

[3] http:psg.bgl.esdm.go.id

[4] https://vsi.esdm.go.id/index.php/gerakan-tanah/kejadian-gerakan-tanah/3199 laporansingkat-pemeriksaan-gerakan-tanah-dan-banjir-bandang-di-kecamatan-masamba-dankecamatan-baebunta-kabupaten-luwu-utara-provinsi-sulawesi-selatan

[5] Setiawan B, Sudarto, Aditya. Pemetaan Daerah Rawan Longsor Di Kecamatan Pujon Menggunakan Metode Analytic Hierarchy Process (AHP). Malang, 2017.

[6] Sugiyono. Metode Penelitian Kuantitatif, Kualitatif dan R\&D. Bandung:PT Alfabet. (2016).

[7] Sunaryo, Adi S, Arief AS. Upaya Mitigasi Bencana Geologi Melalui Zonasi Daerah Potensi Rawan Bencana Longsor Berdasarkan Data Geofisika di Kawasan Payung Kota Batu. Malang, 2019.pp 


\section{JCEJournal Innovation of Civil Engineering}

[8] Tanjung, Amalia, Afrisa, Yesi (2016) Perencanaan Dinding Penahan Tanah Tipe Penyanggah Pada Tebing Sungai Lematang Kabupaten Lahat, Sumatera Selatan. Other Thesis, Politeknik Negeri Sriwijaya.

[9] Widoyoko, Eko Putro. Teknik Penyusunan Instrumen Penelitian. Yogyakarta: Pustaka Pelajar. (2014).

[10] E. Wahyudianto, "Updating the slope-movement data on the Batu-Kediri road network using digital information," 2020, doi: 10.1088/1757-899X/930/1/012031.

[11] E. Wahyudianto, Landslide Hazard Assessment Approach on The Provincial Road in East Java, 2021, Journal Innovation of Civil Engineering, Vol. 2 No.1, pp 1-6.

[12] Priyono, Hubungan Klasifikasi Longsor, Klasifikasi Tanah Rawan Longsor Dan Klasifikasi Tanah Pertanian Rawan Longsor, 2015, GEMA, Vol. 49.

[13] Susanti P.D., Miardini A., Identifikasi Karakteristik dan Faktor Pengaruh pada Berbagai Tipe Longsor, 2019, Agritech, Vol. 39 No. 2, pp 97-107.

[14] Hidayat R., Analisis Stabilitas Lereng Pada Longsor Desa Caok, Purworejo, Jawa Tengah, 2018, Jurnal Sumber Daya Air Vol. 14 No.1, pp 63 - 74. 